(2) Open Access Full Text Article

\title{
An analysis of the Bateson Review of research using nonhuman primates
}

This article was published in the following Dove Press journal:

Medicolegal and Bioethics

5 December 2011

Number of times this article has been viewed

\author{
Ray Greek' \\ Lawrence A Hansen² \\ Andre Menache' \\ 'Americans for Medical \\ Advancement, Goleta, ${ }^{2}$ Department \\ of Neurosciences, University of \\ California, San Diego, CA, USA
}

Correspondence: Ray Greek

Americans for Medical Advancement,

225I Refugio Rd, Goleta, CA 93 II7, USA

$\mathrm{Tel}+\mathrm{I} 8056856812$

Fax + I 8054562133

Email drraygreek@aol.com

\begin{abstract}
An analysis of the use of nonhuman primates in biomedical research in the UK, the Review of Research Using Non-Human Primates (the "Bateson Review") was released in 2011. The review was applauded, to varying degrees, by most of the stakeholders in the controversy over using nonhuman primates in biomedical research. However, there has not been a scientific analysis of the review. In this paper, the Bateson Review is examined for both methodology and the science relevant to the use of nonhuman primates in biomedical research. The relevant science includes complexity theory, evolutionary biology, genetics, empirical evidence regarding the reliability of interspecies extrapolation, and the value of basic biomedical research in general in making discoveries that lead to human treatments. The authors of this paper conclude that the Bateson Review does not meet the criteria for a scientific assessment, in part, because it fails to consider the current science that impacts on the practice of using animals, in general, and nonhuman primates, specifically, in biomedical research. This lack of scientific consideration has legal and ethical ramifications. Since the Bateson Review fails as a scientific evaluation, the ethical and legal recommendations that are based on science are also suspect.
\end{abstract}

Keywords: medicine, complex, evolution, ethics, primate, research

\section{Introduction}

The use of nonhuman primates (NHPs) in medical research and testing is a contentious issue from two perspectives. The first issue is ethical. Primarily because NHPs share so many characteristics with humans, many people find it ethically objectionable to use NHPs as subjects in research and testing. Worldwide, it is estimated that between 100,000 and 200,000 NHPs are used in research and testing each year, mostly in Europe, Japan, and North America. ${ }^{1}$ The most commonly used species are baboons (Papio spp.), crab-eating macaques (Macaca fascicularis), rhesus macaques (Macaca mulatta), and vervet monkeys (Chlorocebus aethiops). ${ }^{2}$

The use of these animals raises several ethical issues, ranging from purely welfare considerations to wildlife conservation. For example, transportation may involve packing animals singly in crates before being shipped to countries halfway around the globe. It is not uncommon for travel times to last up to 58 hours $^{3}$ and for some of the animals to die before, during, or after transportation to their destination. There are also conservation issues. The rhesus macaque was once the species most commonly used for toxicity testing. In the 1960s and 1970s, researchers documented a drastic decline in wild rhesus macaques, as they were being captured in large numbers for export to Western laboratories. ${ }^{4,5}$ The Indian government subsequently banned primate exports in 1978, a ban upheld to this day. The resulting decline in available 
rhesus macaques led to an increase in use of the crab-eating macaque. This is now the species most regularly used in toxicology testing ${ }^{6}$ and forms the overwhelming majority of primate imports to the $\mathrm{UK}^{7}$ and USA. ${ }^{7-9}$ The crab-eating macaque is currently the most heavily traded mammal listed in the Convention on International Trade in Endangered Species of Wild Fauna and Flora (CITES). ${ }^{3,10}$

The second issue is science based. Despite the presence of obvious shared traits, some have pointed out that the evolutionary distance between two differently complex systems - humans and NHPs - is reason to question just how much can be extrapolated from one group to the other. ${ }^{11,12}$ NHPs are used in many fields of research but especially in research on infectious diseases, neuroscience, and organ transplants. ${ }^{2,13}$ They are also used extensively in the testing of pharmaceutical products. There are scientific issues to be addressed with respect to the validity of using NHPs as predictive models of human outcome. ${ }^{11,12,14-20}$

The use of NHPs in research is ethically contentious, mainly in terms of invasive research on NHPs in laboratories. Emotions are not raised to a fevered pitch over observational studies in the wild or of NHPs already in zoos. Moreover, studying macaques in order to learn more about macaques is not scientifically controversial. The authors of this paper believe the impetus for the Review of Research Using NonHuman Primates (the "Bateson Review") $)^{21}$ was the use of NHPs in invasive research that is portrayed as highly important for advancing human medical care. Therefore, this present paper devotes considerable attention to the question of the scientific legitimacy of the use of NHPs in such research and focuses specifically on aspects of the science that were left out of the Bateson Review.

This paper includes the following.

1. General criticism of the Bateson Review.

2. An examination of the history of basic research in general, because:

a. most basic research in biomedical research involves the use of animal models, ${ }^{14}$ and

b. much of the research in the Bateson Review addresses the use of NHPs in basic research.

3. A discussion of interspecies extrapolation in light of the best current science that is relevant to the issue. Specifically, the ramifications of the fact that NHPs are complex systems and that they have different evolutionary trajectories from humans are reviewed. This was ignored in the Bateson Review.

4. An examination of the empirical evidence in an effort to determine the historical reliability of extrapolating the results from research that uses NHPs. This evidence is compared and contrasted with the fact that different humans respond significantly differently to drugs and disease and note that the same science explains both situations. This was also ignored in the Bateson Review.

5. A brief outline of the ethical, legal, and financial implications of what current science reveals about interspecies extrapolation.

\section{The Bateson Review critique: general}

In 2006, the Weatherall report, The Use of Nonhuman Primates in Research, ${ }^{22}$ attempted to address some of the concerns regarding the use of NHPs in research. The aim of the Weatherall report was to "examine the scientific case for the use of non-human primates for research into the prevention or treatment of disease, or for fundamental research that has the long-term potential of achieving the same end." Of particular relevance to this paper is one of the report's major recommendations, recommendation 4, which states: "As part of their ongoing programmes to assess the outcomes of their research, the major funding organisations should undertake a systematic review of the outcome of all their research using non-human primates supported over the last decade."21,22

The Medical Research Council, a major sponsor of the Weatherall report, responded to this recommendation in 2011 by producing a document entitled Review of Research Using Non-Human Primates ${ }^{21}$ (see Figure 1), whose panel of experts was chaired by Sir Patrick Bateson. (The media decided to call it the "Bateson Review" and, as mentioned, this is how it is referred to in this present paper.) The reference to a systematic review is apparent in the opening paragraph of the executive summary, which states, "In 2006 a Working Group chaired by Sir David Weatherall recommended (Recommendation 4) that the major funding organisations should undertake a systematic review of the outcome of all their research using non-human primates (NHPs) supported over the last decade." 21

The raison d'être of the Bateson Review appears, at first glance, to fulfill the need for a Cochrane-style ${ }^{23}$ systematic review of studies involving NHPs. However, the Bateson Review states: "the review could not be a 'systematic' review in the formal sense normally used in medical research, as the research in question does not lend itself to that approach." The explanation for this is attributed to the different methodologies used, small sample sizes, and variation in the quality of the reporting on some of the studies. ${ }^{10}$ Systematic reviews are currently in fashion, despite criticisms of them that can be 


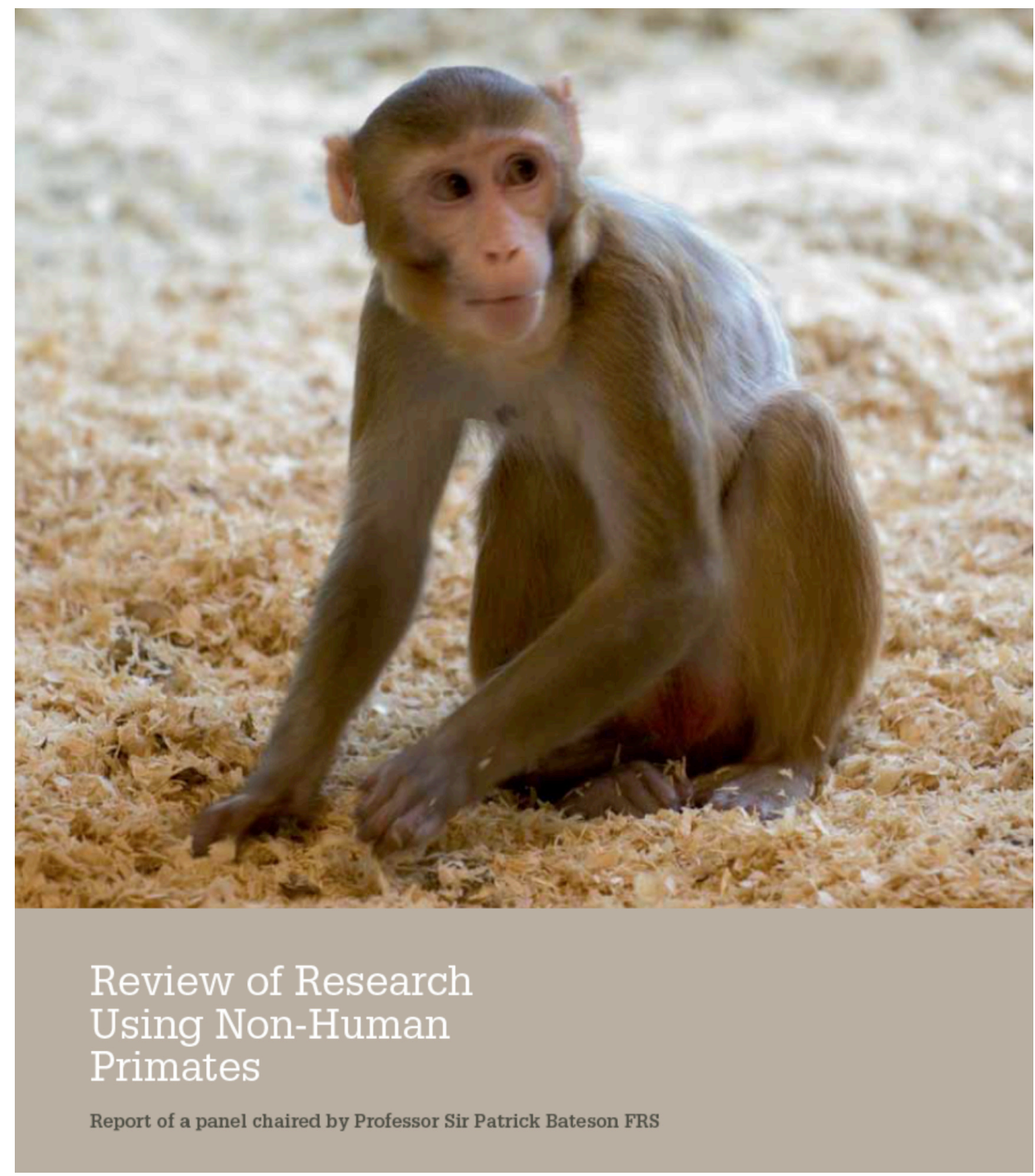

Figure I The Bateson Review.

Note: Figure @ Medical Research Council/Wellcome Trust. Reproduced with permission.

summed up as "garbage in, garbage out." That is, systematic reviews are only as good as the data they review; regardless, systematic reviews currently do have a certain cachet.

Even if it is agreed that a systematic review could not be achieved, there are review articles that summarize the current state of knowledge on a subject. Such articles include the following.

1. A broad presentation of the subject under consideration.

2. Analysis of specific aspects of relevant research.

3. References to all or most of the important publications.

4. A theoretical consideration of the issues being raised in light of the current science from other fields consilience.

5. A brief analysis of the more important challenges and how they can be met.

6. Language consistent with the science of the field.
The Bateson Review fails to fulfill essentially all of the above standards; thus, according to the National Library of Medicine's description, it cannot qualify as a standard review article either. ${ }^{24}$

The Bateson Review states that it sought to:

- Assess the quality, outputs and impacts of research in this area on advancing knowledge in human and animal health;

- Identify the strengths and weaknesses of the funded science in this field;

- Inform their future science and funding strategies; and

- Feed the outcomes of the review into any Government strategy on NHP use.

The research studied was evaluated for:

1. The scientific quality and importance of the research;

2. The probability of medical and public benefit; and

3. The likelihood of animal suffering. 
To accomplish the above, the panel examined 67 questionnaires involving NHP studies conducted between 1997 and 2006 that were funded by the Biotechnology and Biological Sciences Research Council (BBSRC), the Medical Research Council, and the Wellcome Trust. The questions focused on the scientific quality of the research, welfare costs to the animal, and what benefits to medicine the studies produced. ${ }^{21}$

Of the 67 questionnaires considered in the Bateson Review, nearly half (46.2\%) related to grants in the area of neurobiology. Most studies utilized macaques as experimental animals. The justification for using NHPs was that an understanding of development and normal functioning are a prerequisite to devising medical solutions to human psychiatric conditions, in addition to Parkinson's disease, Alzheimer's disease, schizophrenia, bipolar disorder, obsessive compulsive disorders, and stroke. This assumes that one can learn the normal functioning of the human brain from studying a nonhuman brain. There are strong reasons from evolutionary biology and complexity science to question this. Regardless, in its overall assessment, the Bateson Review states that "in most cases, however, little direct evidence was available of actual medical benefit in the form of changes in clinical practice or new treatments." Nevertheless, the panel qualified this observation by adding the caveat that the time that elapsed between the research and the review may have been too short for a move to practical applications to be seen. ${ }^{21}$

A key issue addressed by the Bateson Review was the extent to which advances in fundamental or basic science were effectively translated into applied research and practical application. As an example, a study (not cited) into two specific neurotransmitter systems aimed at target validation through receptor mapping led to publication but did not lead to sustained drug development in the 2 years since the work had been completed. Another study (not cited), characterized by the panel as "one of the best grants reviewed," had focused on mapping the spatial dissociation of different cognitive processes in the frontal lobe and was published in several journals, although the subsequent overall citation rate was "disappointing." ${ }^{21}$ The panel similarly assessed several other areas of research covered in the questionnaires. These included vision, immunology and infectious disease, reproductive biology, and imaging technologies.

The panel studied progress reports from researchers (these were not made available), papers published (these were not listed), and evaluated the answers to a questionnaire that was filled out by the researchers (also not available).
A bibliometric analysis was also commissioned. It should be noted that the Bateson Review relies almost exclusively on the opinion of the researchers themselves for information regarding their research efforts and results. The researchers filled out the questionnaires, the articles were written by the researchers, and the researchers filled out the progress reports. Granted, the panel reviewed all of this and evaluated a bibliometric analysis, but no other input was requested. While this situation does not ipso facto invalidate the conclusions, it is cause for concern.

Moreover, bibliometric analyses have been criticized in the past based on the fact that impact factors "suffer from two problems: (i) citation behavior varies among fields of science and therefore leads to systematic differences, and (ii) there are no statistics to inform us whether differences are significant. ${ }^{25}$ In this case, no citations/references were provided for independent analysis, but a vast majority of the studies had a normalized citation impact $(\mathrm{NCI}) \leq 1$. This is largely meaningless, however, as the Bateson Review did not define what the NCI was nor how it was calculated. The reader was assured that the papers reviewed were above average, but no details were made available. An Internet search revealed numerous ways of calculating impact factors, some of which had the word "normalized" in them, but there did not appear to be one standard.

This brings us to the composition of the panel. Sir Patrick Bateson, DSc, FRS, was employed by the University of Cambridge, first as a behavioral biologist and later as Provost of King's College, and has vast experience experimenting on animals. ${ }^{21,23,24,26-39} \mathrm{He}$ clearly has a vested interest in animal experimentation. Heidi Johansen-Berg, DPhil, conducts neurological studies on animals and has coauthored numerous papers that involved invasive research on monkeys. ${ }^{40-44}$ She clearly has a vested interest in animal-based research. Derek K Jones, PhD, Dip IPSM, conducts research mainly with humans but has published a paper based on pig research. ${ }^{45}$ The Bateson Review acknowledges that Eric Barrington Keverne, DSc, FRS, FMedSci has extensive research experience using animals. Paul M Matthews, OBE, MD, DPhil, FRCP, while working primarily with humans, has coauthored numerous papers involving animal experiments, including experiments on monkeys. ${ }^{46-48} \mathrm{He}$ has also worked at numerous institutions where animal experiments, including experiments on monkeys, are performed. The Bateson Review acknowledges that Arthur David Milner, PhD, FRSE, FRS, has conducted neurological animal-based research. ${ }^{49,50}$ Mark Prescott, $\mathrm{PhD}$, has studied monkeys in the wild and in captivity. He currently sits on ethics committees and is 
employed by the National Centre for the Replacement, Refinement and Reduction of Animals in Research, which states in its mission statement that: "Many areas of medical, veterinary and biological research and testing currently depend on the use of animals." The National Centre for the Replacement, Refinement and Reduction of Animals in Research also funds research using NHPs. Ian Ragan, $\mathrm{PhD}$, has a long history in the pharmaceutical industry, specifically in the neuroscience research area. Robin Shattock, $\mathrm{PhD}$, studies human immunodeficiency virus (HIV) and is well known for his research with macaques. ${ }^{51-56}$ Jerome Strauss III, MD, PhD, has served on advisory boards for NHPs centers in the USA and has extensive experience using animals in research. The Bateson Review points out that, on three occasions, during discussion of specific researchers, one member of the panel withdrew from the discussion, citing conflict of interest.

The panel, therefore, was composed primarily, if not exclusively, of people with a vested interest in using animals in research. The phrase "vested interest" was coined by Crano in $1995^{57}$ and refers to the explanatory power that can be attributed to the pleasure a position-holder derives from maintaining that position. In most cases, including the above, the interest is financial. The panel member either conducted research with NHPs such as macaques or other animals or was employed by an institution where such studies took place. The other aspect of a vested interest is an attachment to a position because of emotions like pride and ego. If a panel member devoted a substantial amount of his or her career to experimenting with animal models, then it is maintained by the authors of this paper that such involvement does result in an emotional attachment to the position that such research is scientifically valid. In some cases, there was an additional conflict of interest in that a member was involved in research with NHPs in one of the areas singled out for study. Considering the issues the panel sought to address, the composition of the panel invites accusations of conflicts of interest and an inattention to choosing panel members, if not outright manipulation. Considering how many people on the panel formerly participated or currently participate in some form of animal experimentation and/ or represent or represented institutions that perform research using animals, including NHPs, the authors of this present paper do not think the Bateson Review panel to be unbiased.

Such a composition is not a death knell for the report. At times, the only experts available are people with a vested interest in the subject. At other times, even if there were other experts available, the people with a vested interest can be fair and produce unbiased results. The report must be judged on its merit.
The overall conclusion of the Bateson Review was that: "In many cases the use of non human primates was justifiable even in the context of current understanding of animal welfare and advances in knowledge that might now render some work on living animals unnecessary." ${ }^{21}$ In other words, even when there were nonanimal methods available, or that would be available soon, the panel concluded that research with NHPs was justified. It is difficult to take seriously a position that voices opposition to the nonessential use of NHPs in research but which goes on to condone such research. Not surprisingly, in light of the above, the Bateson Review endorsed the status quo, speaking in platitudes, signifying no changes needed. The only matters that needed urgent consideration were the cost of research that uses NHPs and the harassment, by animal activists, of researchers that use NHPs. A typical statement follows:

In the area of neuroscience, the majority of research grants were well-focused on important areas of either biological or medical concern. The level of welfare challenge imposed on the research animals could be justified by the quality of the science or, in some cases, the actual or potential medical benefits accrued. [Reproduced with kind permission of MRC, BBSRC, and The Wellcome Trust.]

The following was also stated numerous times in various ways: "In general, scientific research carried out in the UK is highly regarded worldwide. The best of the work carried out on NHPs in the UK is as good as the best of the work carried out in other fields." Statements like these make it appear that the panel was more interested in defending the reputation of British scientists who conduct research using NHPs than in objectively analyzing the research itself.

Comments on the Bateson Review were mostly favorable. The following is from the BBSRC website:

"Sir Patrick's report rightly recognises the high quality of biomedical research involving non-human primates in the UK," says Sir Mark Walport, Director of the Wellcome Trust. "We agree that non-human primates should only be used when no other potential animal models are viable and when human subjects cannot be used as alternatives. The number of experiments carried out in the UK is relatively small, but such research is vital in helping us to better understand human physiology and disease." ${ }^{58}$ [Reproduced with kind permission of BBSRC.]

Senior scientist for the Royal Society for the Prevention of Cruelty to Animals (RSPCA), Maggy Jennings, stated: "We agree with Bateson that for too long people have been 
happy to overstate the importance of experiments using non-human primates in the absence of the evidence to back up their emphatic claims. ${ }^{559}$ Kailah Eglington, Chief Executive of the Dr Hadwen Trust, stated: "The report recommends that existing alternative approaches be used. We've consistently funded and promoted the use of alternatives with an ethical, scientific and economic perspective for more than forty years." ${ }^{90}$ Some in the media ${ }^{61}$ reported that the Bateson Review stated that the panel was unable to find clear benefit for about $9 \%$ of the studies. While the review certainly did state this, reading the statement in context one is overwhelmed by the number of statements confirming the necessity of using NHPs. Science journals that publish research using NHPs reported on the Bateson Review using positive terms. ${ }^{62}$

Notably absent from the comments, be they comments from the scientific community or the animal protection community, was any reference to the scientific quality of the Bateson Review. Did the panel evaluate NHP research by using the best science currently available that is relevant to the issue? What areas of science are relevant to this issue, and what contribution do they make in terms of informing society about this issue? This analysis now turns to that subject.

\section{The Bateson Review critique: basic research}

The Bateson Review states:

The Weatherall group reported cases where fundamental research had led to major advances in medicine and also discussed cases where search for an understanding of fundamental biological processes proceeded hand-in-hand with clinical research. The group concluded therefore that "in assessing the importance of biological science for our future well-being, the question of whether a piece of research is fundamental or applied science has become outdated. The study of normal function, as well as being central to our understanding of why we are what we are, is often a vital step in the elucidation of the mechanisms that underlie its breakdown in disease. The central issue is whether a programme of research is directed at an important biological or medical question and is designed in a way that has a reasonable chance of answering that question; hence the importance of the case-by-case assessment that forms the basis of UK legislation and practice around animal research." The group also mentioned the well-known paper by Comroe and Dripps who showed how an advance in medicine depended on findings obtained many years beforehand from research conducted without concern for medical benefit. ${ }^{21}$ [Reproduced with kind permission of MRC, BBSRC, and The Wellcome Trust.]

The above brings several issues to the fore.

1. "Basic research" can be variously defined. The Organisation for Economic Cooperation and Development defines it as: "Experimental or theoretical work undertaken primarily to acquire new knowledge of phenomena and observable facts without any particular application or use in view" (emphasis added). ${ }^{63}$ There is no doubt that research is a continuum ranging from basic to applied, and it is not always easy to categorize a specific research project. But, based on definitions like the one above, basic research (also called blue-sky, fundamental, and basic science research) makes no claims of applicability. This argument is well described by Greek and Greek $2010 .{ }^{14}$ The Bateson Review appears to use the phrase to mean, "attempts to discover the fundamental properties of living systems." Regardless of the exact definition, all agree that basic research is not translating to treatments for humans.

Adler, the inventor of the CyberKnife states: "Basic research is healthy in America. But patients aren't benefiting." ${ }^{\circ 4}$ An editorial in Nature states: "The uncomfortable truth is that scientists and clinicians have been unable to convert basic biology advances into therapies or resolve why these conversion attempts so often don't succeed." ${ }^{95}$ Rosenberg calls the assumption that "recent exponential growth of scientific information about disease, as evidenced by the substantial increase in the numbers of published articles in biomedical journals, heralds a rapid move to improve human health" an illusion. ${ }^{66}$ Pound et al state: "Clinicians and the public often consider it axiomatic that animal research has contributed to the treatment of human disease, yet little evidence is available to support this view. ${ }^{97}$ Ioannidis writes: "There is considerable evidence that the translation rate of major basic science promises to clinical applications has been inefficient and disappointing." 68

2. The notion that scientists must understand the mechanisms of disease and drugs in order for breakthroughs and advances has long been put forth by basic researchers. In fact, understanding mechanisms has resulted in advances. However, scientists now acknowledge that they have learned much about apparent mechanisms by studying animals but that this has not translated into treatments. ${ }^{64,69-77}$ Marincola summarizes the situation:

It is surprising how often a manuscript is dismissed

by reviewers as "just descriptive", regardless of the novelty of the reported observation. On the 
other hand, we have not once received a negative comment on a "mechanistic" study, even if it lacks proof of the validity of the experimental model and its relevance to human disease. Such studies are automatically given the benefit of the doubt based on predictable rationalizations vaguely offered in the introductory paragraphs. As a consequence, innumerable conflicting results are published, each one a reflection of its own experimental bias. ${ }^{76}$

Furthermore, many advances have not depended upon knowledge of mechanisms. Arguably the greatest advance in terms of decreasing suffering was the discovery of general anesthesia. This was the result of serendipity and the mechanisms for general anesthesia are still unknown. Many other drugs have saved lives despite their mechanisms being unknown. Unfortunately, the current focus in research appears to be on mechanisms not treatments.

3. Basic research using animals or NHPs is not the only means of conducting basic research. Arguably, the greatest advances in the past decades have come from engineering combined with basic research in the physical sciences of chemistry and physics. ${ }^{78-81}$

4. The difference between basic and "applied" research is not "outdated," although it would be to the benefit of basic researchers if society thought such was the case. Conflating basic research, which by definition holds out no promise for cures, with applied research, which does, allows basic researchers to have the best of both worlds. The basic research community can obtain grants based on the promise of cures, but when said cures are not forthcoming, it can fall back on the fact that basic research is not designed to find cures. There are very different standards for basic and applied research. An occasional idea that results from basic research on animals is acceptable in terms of the standards for basic research. Applied research, like drug development, seeks $100 \%$ predictive ability to questions like: "Will the drug be efficacious?" and "Will the drug be toxic?" The acceptable success rates for each practice are very different, as they should be considering the questions each is asking. Regardless, bait and switch is not a viable defense of an industry or practice.

5. The Bateson Review expresses concern that the low rate of transfer between basic research and clinical application was secondary to the fact that the studies they chose were not as old as other studies that historically have shown a transfer of knowledge. This is a red herring, as the panel picked the studies knowing how long it takes for basic research to find application in medical science. If the panel had wanted to conduct a study like the ones by Grant et al ${ }^{82-85}$ and Contopoulos-Ioannidis et al, ${ }^{72}$ described below, they could have done so. Having decided not to engage in such a study, they cannot ignore the results of such studies.

6. Their statement that research in general should have "a reasonable chance of answering that question" is, however, relevant as is their reference to the Comroe and Dripps ${ }^{86}$ study. The importance of basic research in the overall scheme of medical research dates back to their study in $1976 .{ }^{86}$ Comroe and Dripps, much like the Bateson Review, sent surveys to scientists and essentially asked them to evaluate the role of basic research in medical advances. Many of the scientists were basic researchers and, unsurprisingly, Comroe and Dripps concluded that basic research was essential to medical progress. The study, with rare exceptions ${ }^{87}$ went unchallenged for decades. In the early $2000 \mathrm{~s}$, Grant et a ${ }^{82-85}$ studied the methodology of Comroe and Dripps and came to some startling conclusions. Grant et al concluded that Comroe and Dripps was "not repeatable, reliable, or valid." 84 (For more on the relevance of Grant et al to using animals in research see Greek and Greek. ${ }^{14}$ )

The question of the translation rate of basic research in general into clinically useful treatments has also been addressed by other authors. Since a majority of basic biomedical research is animal based, the present authors conclude that the following studies are representative of basic research that uses animals even though the studies examined basic research in general. ${ }^{14}$ In 2003, Contopoulos-Ioannidis et $\mathrm{al}^{72}$ quantified the translation rate of "highly promising" basic research into clinical applications. Their study revealed that, of 101 basic research papers published in the high-profile journals Nature, Cell, Science, Journal of Biological Chemistry, Journal of Clinical Investigation, and Journal of Experimental Medicine between 1979 and 1983, 27 led to randomized clinical trials, and five eventually gave rise to licensed clinical application. They concluded that "[e]ven the most promising findings of basic research take a long time to translate into clinical experimentation, and adoption in clinical practice is rare." ${ }^{.2}$

Contopoulos-Ioannidis et al ${ }^{72}$ actually searched all the articles published in the abovementioned journals between 1979 and 1983, a total of around 25,000. This was commented upon by Crowley, ${ }^{73}$ who observed that, "[o]f the 25,000 articles searched ... $100(0.4 \%)$ resulted in a clinical trial and only one $(0.004 \%)$ led to the development of a clinically useful class of drugs (angiotensin-converting enzyme inhibitors) ..." In the 
case of angiotensin-converting enzyme inhibitors, the discovery was not due to animal studies, but rather the result of rational drug design. ${ }^{88}$ The drugs were eventually tested on animals but, as this paper shall discuss presently, animal models cannot predict properties such as efficacy or toxicity. The Crowley analysis would suggest that the transfer rate of basic research into clinical use is very low indeed. This in turn, raises questions about the efficacy of basic research involving NHPs, which, although may be considered by some as valuable for its own sake, even when treatments are not forthcoming, must be weighed against other research modalities that could be funded with the same resources. These concerns are, of course, in addition to other considerations, such as animal suffering, conservation, and societal misgivings associated with invasive NHP research.

Other studies have similarly revealed that basic biomedical research that uses animals is of limited value in finding treatments. Lindl et $\mathrm{al}^{89}$ studied applications for animal-based research in Germany, from 1991 to 1993, that lead to publications. They found that "only 4 publications evidenced a direct correlation between the results from animal experiments and observations in humans $(0.3 \%)$. However, even in these 4 cases the hypotheses that had been verified successfully in the animal experiment failed in every respect." 89 This casts further doubt on the position that basic research using animals is worth the cost.

Hackam and Redelmeier" conducted a "systematic review to determine how often highly cited animal studies translate into successful human research." They searched the seven highest-rated journals, judged by citation factor, and chose the 2000 most cited articles, published from 1980 to 2000 . Of the relevant animal studies, 37\% were "replicated in human randomized trials," and eight of these led to therapeutic interventions. However, $18 \%$ were "contradicted by randomized trials," while $45 \%$ had not been tested against human data. Hackam and Redelmeier noted that the likelihood for animal studies in general translating to human was probably lower than they reported as they purposefully chose the studies most likely to translate to humans. This caution seems reasonable, as hundreds of drugs have been neuroprotective in animals but none have been protective in humans, ${ }^{91,92}$ cancer cures have been almost nonexistent despite demonstrating efficacy in animal models, ${ }^{71,93-100}$ and scores of HIV vaccines have protected monkeys, however none have been efficacious in humans. ${ }^{101,102}$ Hackam and Redelmeier concluded by stating: "First, patients and physicians should remain cautious about extrapolating the findings of prominent animal research to the care of human disease ... Finally, poor replication of even high-quality animal studies should be expected by those who conduct clinical research." 90 The true failure rate of basic research is unknown because most negative findings are not published. The above estimates are probably several orders of magnitude off. Geerts states: "the reporting of positive trials far outweighs the reporting of negative or failed clinical trials, very probably because of economic or investment reasons. In addition, trial data are considered by US law to be proprietary property of the sponsor."103

Another indication of the importance of basic research in providing information relevant to human disease is the number of new drugs approved each year. Munos stated: "the number of new drugs that are approved annually is no greater now than it was 50 years ago." ${ }^{104}$ Along those same lines, while the above did not address the use of NHPs specifically, drug toxicity testing does use NHPs, and the results of that enterprise are well known. Animals, including NHPs, fail to predict human toxicities and efficacy. ${ }^{103,105-114}$ An editorial in Nature Reviews Drug Discovery declares: "Unpredicted drug toxicities remain a leading cause of attrition in clinical trials and are a major complication of drug therapy."115

The actual results from years of high-priority funding to basic research are forcing some within the research community to acknowledge the failure of basic research to provide data that leads to treatments. Rothwell stated in the Lancet in 2006: "Indeed, most major therapeutic developments over the past few decades have been due to simple clinical innovation coupled with advances in physics and engineering rather than to laboratory-based medical research."78 Steinman states: "Patients have been too patient with basic research. Most of our best people work in lab animals, not people. But this has not resulted in cures or even significantly helped most patients." 70 These examples are easily multiplied. ${ }^{66,74-76,85,116-122}$

7. The position that the merit of NHP research must be evaluated on a case-by-case basis is assessed in the next section.

Because the Bateson Review ignored the above studies, it lacks scientific rigor; hence, the authors of this present paper reason that its conclusions regarding the use of NHPs in basic research are unfounded, irrespective of the other flaws in the Review. This present paper now turns to the second area of science the Bateson Review ignored. 


\section{Science the Bateson Review ignored: evolved living complex systems}

The modern foundation for animal use in research, be that research basic or applied, was the nineteenth-century creationist position that all animals were essentially the same, provided scaling for size was taken into account. ${ }^{123,124}$ LaFollette and Shanks state:

Bernard's particular understanding of hypotheticodeductivism, coupled with his rejection of all statistical laws, led him to assume that clinical medicine (including epidemiological studies) could never be a genuine science. Perhaps, though, he would have given more consideration to clinical medicine had he not believed he had a rigorous science ready to hand in the animal laboratory. However, Bernard believed in the interchangeability of species; he thus had reason to assume clinical hypotheses could be tested by laboratory experiments on animals. ${ }^{123}$

The medical historian Elliot comments on the fact that the physiologist, and father of current animal-based research, Claude Bernard was a creationist:

Leading French biologists, such as Bernard himself and Charles Robin, were resistant to the Darwinian theory of evolution.... [Bernard and others] resisted these ideas because they saw them as the results of speculation unsupported by proper experimental evidence. The emergence of experimental physiology based on vivisection was therefore an integral part of a general trend in French science away from anything that could be interpreted as speculation towards a science based rigidly, too rigidly perhaps, on laboratory work and experiment. ${ }^{125}$

Bernard was not a creationist in the current sense of the concept, the theory of evolution had not been fully developed during his time, but he was a creationist and this did influence his position. ${ }^{123}$ This position directly related to Bernard's stance as a strict causal determinist, meaning that if $\mathrm{X}$ caused $\mathrm{Y}$ in a monkey, then it would also cause $\mathrm{Y}$ in a human. Bernard states: "Physiologists ... deal with just one thing, the properties of living matter and the mechanism of life, in whatever form it shows itself. For them genus, species and class no longer exist." 124 Bernard's position of causal determinism was also based on the Cartesian position of determinism, which led to the method of study in science known as reductionism. Reductionism basically means reducing the system being studied to its component parts, discovering the role of each part, and using that information in order to deduce the function or role of the whole system. Reductionism worked well for the physical sciences and the life sciences up to a point. Reductionism still plays a valuable role in science that studies simple systems; however, reductionism is not the only way, or even a viable way in some cases, to study complex systems. Times have changed, but underlying assumptions, unfortunately, have not changed sufficiently. Because of the close evolutionary relationship between humans and NHPs, the assumption is made that NHPs will provide a living intact system that more closely resembles humans. Therefore, by extension of this assumption, the study of gene function, drug and disease response, and basic neurophysiology is more likely to mimic that of humans.

Complexity science concerns the study of systems that have specific characteristics that disqualify them from a complete evaluation using only reductionism. Arguably, the most important of these characteristics is that the whole is greater than the sum of the parts. Even if a scientist can reduce an entire complex system to its components, he will still not understand the system as a whole. Other characteristics of complex systems include: a hierarchy of levels of organization; emergence - the presence of traits not predicted even in light of complete knowledge of the underlying levels; adaptation; modularity; self-organization; dependence upon initial condition; robustness and redundancy; and nonlinearity - perturbations to the system may result in large changes or no changes at all. Complex systems cannot adequately be described by the linear cause and effect relationships that reductionism assumes. ${ }^{126-134}$

Van Regenmortel acknowledges that reductionism has been important to science, although currently, reductionism "has an increasingly detrimental influence on many areas of biomedical research, including drug discovery and vaccine development." 129 Jura et al comment that living organisms cannot be assumed to have a linear relationship among variables. ${ }^{127}$ Grove states: "Humans are incredibly complex biological systems, and working with them has to be subject to safety, legal, and ethical concerns ... The result is wide-scale experimentation with animal models of dubious relevance, whose merit principally lies in their short lifespan." 135

Reductionism allows extrapolation between simple systems and even between complex systems, provided the level being examined can be isolated and treated as a simple system. However, living complex systems are differently complex because evolution has profoundly changed the initial conditions. These changes include:

- Different background genes that influence the genes being perturbed by drugs or disease. 
- The presence of different molecules that perform the same function.

- Alternative splicing, which allows one gene to form or be part of forming many different proteins.

- Different genes.

- Different gene-gene interactions.

- Different proteins and different protein-protein interactions.

- Different gene-protein interactions.

- Old genes can evolve to perform new functions.

- Horizontal gene transfer.

- The presence of modifier genes.

- Differences in the regulation and/or expression of genes.

- Gene fossilization.

- Convergent evolution.

- Epigenetics.

- Mutations such as single nucleotide polymorphisms, copy number variants, and gene and/or chromosome duplications, inversions, deletions, and insertions.

A mutation in a single gene may affect seemingly unrelated pathways. ${ }^{136,137}$ Moreover, the effects may vary between species and even strains of species. ${ }^{14,129,138-153}$ In part, this can be due to differences in background genes or modifier genes. ${ }^{137,141,154-159}$ Agarwal and Moorchung state:

It is now increasingly apparent that modifier genes have a considerable role to play in phenotypic variations of singlegene disorders. Intrafamilial variations, altered penetrance, and altered severity are now common features of single gene disorders because of the involvement of several genes in the expression of the disease phenotype. Oligogenic disorders occur because of a second gene modifying the action of a dominant gene. It is now certain that cancer occurs due to the action of the environment acting in combination with several genes. Although modifier genes make it impossible to predict phenotype from the genotype and cause considerable difficulties in genetic counseling, they have their uses. ${ }^{160}$

Genes also work in networks that can vary among species and are differently regulated, thus leading to different expression patterns. Thus, conserved processes are also subject to different environments and influences. ${ }^{161,162}$ The same genes can be used in such a way as to result in dramatically different phenotypes. ${ }^{163}$ Ptashne and Gann ${ }^{164}$ state that:

It is generally believed that mammals - humans and mice, for example - contain to a large extent the same genes; it is the differences in how these genes are expressed that account for the distinctive features of the animals ... changes in patterns of gene expression (rather than evolution of new genes) have had an important, perhaps even determinative, role in generating much of that diversity (that occurred during the Cambrian explosion) ... a relatively small number of genes and signals have generated an astounding panoply of organisms. Thus, the regulatory machinery must be such that it readily throws up variations - new patterns of gene expression - for selection to work on. [Reproduced with permission of the publisher and copyright holder, Cold Spring Harbor Laboratory Press.]

Levine states: "The evolution of the genetic diversity of animal forms is really due to differences in gene regulation." 165 The notion that regulatory genes are responsible for major changes during evolution is now more or less universally accepted. ${ }^{60}$ Gene expression varies greatly in humans ${ }^{166-169}$ and in animals. ${ }^{170-173}$ There are other genetic changes that have implications for interspecies extrapolation. "Add-ons" (as discussed by Ptashne and Gann ${ }^{164}$ ), are genetic alterations over time, usually in the form of additions to preexisting systems of genes.

The above has been empirically confirmed. Marvanová et al used human microarrays to profile genes from brains of human, macaque, and marmosets and combined this with available data from chimpanzee and orangutan to create a dataset that revealed similarities and differences in expression of genes underlying Alzheimer's, Huntington's, and Parkinson's diseases. ${ }^{174}$ They found that a large number of genes are expressed in human prefrontal cortex and that a significant percentage of these are also expressed in NHPs. But they also found profound differences:

\begin{abstract}
Approximately $20 \%$ of present human genes had a different expression profile ( $>2$-fold change) in chimpanzees and $>25 \%$ of genes in orangutan, macaque, and marmoset had a different expression profile ... The percentage of genes present in prefrontal cortex and displaying a different expression level ( $>2$-fold change) was chimpanzee, 18\%; orangutan, 37\%; macaque, 26\%; marmoset, 33\% ... Genes involved in common neurodegenerative diseases $\mathrm{AD}, \mathrm{PD}$, and $\mathrm{HD}$ contained qualitative and quantitative differences in NHP PFCs. ${ }^{174}$
\end{abstract}

(For more examples, see Shanks and Greek. ${ }^{11}$ ) Considering the fact that a very small difference between two complex systems can lead to very divergent outcomes, these differences are not insignificant.

The lineage leading to modern chimpanzees diverged from the lineage leading to modern humans about 7 million 
years ago (about the same amount of time separating deer from giraffes). It is certainly true that from an evolutionary standpoint, we expect there to be fewer differences between humans and chimpanzees than between humans and mice or humans and yeast. However, there are differences (see Tables $1,{ }^{175} 2,{ }^{176}$ and $3^{176}$ ) and, considering the fact that humans and chimpanzees are complex adaptive systems, it should be expected that these genetic differences will result in significant differences in response to perturbations such as drugs and disease.

These changes in initial conditions of living complex systems such as NHPs and humans, alone, are enough to expect different outcomes from the same perturbation such as a drug or disease. It can also explain why different individual humans respond differently to drugs and disease. Based on the characteristics of complex systems, one should anticipate that interspecies extrapolation of outcomes that occur at higher levels of organization will be the exception rather than the rule. Current biomedical research is studying disease and drug response at the level where the differences between complex systems (be they two different species or two different humans) manifest, hence using animals, even NHPs, as predictive or causal analogical models ${ }^{177}$ for human disease and drug testing is scientifically invalid. In addition, the human brain is considered the most complex entity in the known universe. If there is one area where interspecies extrapolation should not be expected, it is here.

The Bateson Review ignores the ramifications that complexity theory have for interspecies extrapolation as well as the fact that evolution has resulted in living complex systems that vary tremendously in initial conditions, among other areas. The notion that research using NHPs, or any species, must be assessed on a case-by-case basis ignores some of the most impressive advances in science in the last quarter century. If individual humans react markedly differently to drugs and disease (see below) it is unreasonable to think that a different species will predict individual human responses. Because the Bateson Review did not address the implications of extrapolating between living complex systems with different evolutionary trajectories, it cannot be taken seriously as a scientific examination of the issue of using NHPs in research.

\section{Science the Bateson Review ignored: empirical evidence}

The Bateson Review seeks to address whether research with NHPs benefits society, advances knowledge in biology, and/ or advances knowledge relevant to medicine. The question of what benefits society is too broad and ambiguous to be addressed. What one person thinks benefits society, another may think degrades society. This category does not add anything to the analysis.

The question of whether research with NHPs advances biology is tautological. Unless the experiment or research is methodologically ineffectual, then studying living systems will, by definition, add knowledge to the world. Unless the questions being asked are trivial, such research should advance the science of biology. The advances may be large or small, but most scientists would argue that any time more knowledge has been added, biology has advanced. Therefore, the answer to the question of whether the research evaluated by the panel led to advances in biology was a forgone compulsion.

The real question regarding the importance of using NHPs in research revolves around the importance of the research to medical science. The use of animals like NHPs in research is accepted by society only when there is an assumption that very strict criteria have been fulfilled. For example, Giles, writing in Nature, states: "how useful are animal experiments as a way to prepare for trials of medical treatments in humans? The issue is crucial, as public opinion is behind animal research only if it helps develop better drugs" (emphasis added). ${ }^{178}$ Not all advances in science are important or even relevant to the advancement of medical science and medical care. Society is willing to allow the use of sentient animals, especially NHPs, if and only if that research leads to cures or treatments. ${ }^{14}$ The effectiveness of basic research using animals in general has been examined. Therefore, the only remaining question, via Giles, is whether animal models are predictive for humans, vis-à-vis safety and efficacy. This paper will now address that question. There already are reasons to doubt NHPs will be predictive for humans based on the theoretical considerations of the preceding section. This assessment will therefore be completed by examining the empirical evidence.

For a modality or practice to be considered predictive in medical science, it must be tested and found to have a high sensitivity (SN), specificity, positive predictive value (PPV), and negative predictive value (see Figures 2 and 3). Animal models that correlate with human response only occasionally cannot be considered predictive. Moreover, the category "animal models" cannot include all animal species. Each species must be tested individually if one is going to make the claim that this model can predict human response. In addition, the species in question must have a history of correctly identifying efficacy or toxicity or whatever outcome 
Table I Summary of main findings from human and chimpanzee genomes

Category
Nucleotide divergence

Recombination pattern divergence

Divergence/Evolution of proteins

Evolution of the $Y$ chromosome

Human lineage-specific gene inactivation

Divergence in cancer-related genes

Expression divergence

Evolution of transcriptional cis-regulation

Chromosomal differences

Insertions/Deletions

\section{Results}

Number of fixed nucleotide substitutions between PTR and HSA: I\%.

Regional variation in divergence; substitution rates in subtelomeric regions are elevated in hominids as compared to murids.

Higher divergence in 5'and 3' UTRs than in protein coding regions of genes.

Substitution rate at silent sites in exons is lower than at intronic sites, suggesting weak purifying selection operating on silent sites.

Chromosomal variation with highest sequence divergence found on the $Y$ chromosome (I.74\%) and lowest on the $X$ chromosome (0.94\%).

Recombination hotspots appear not be conserved between PTR and HSA.

Genomewide correlation between sequence divergence and recombination rates.

70\%-80\% of proteins are nonidentical between PTR and HSA, although they differ on average by only two amino acid residues.

Average $\mathrm{K}_{\mathrm{A}} / \mathrm{K}_{\mathrm{S}}$ ratio is 0.23 ; the proportion of advantageous mutations in the human lineage is lower than previously estimated but twice that estimated from the mouse-rat comparison (0.13).

$5 \%$ of proteins evolved under positive selection specifically in the human lineage. Proteins that have experienced adaptive evolution have been identified in many functional categories. Those associated with brain function/development may have been intimately involved in the evolution of human-specific traits.

The absence of any loss or decay of $X$ degenerate genes in HSA as compared to PTR does not favor the "impending demise hypothesis" for the human Y chromosome.

Gene loss or inactivation has not been a rare event during human evolution after the separation from PTR; 90 examples so far known.

Adaptive inactivation which has not yet been completely fixed in the human population has been demonstrated in only one case (CASPI 2 gene)

High degree of overall conservation but a total of I,542 amino acid changes were identified that could contribute to differential cancer susceptibility in PTR and HSA.

The highest degree of expression divergence has been observed in the testis, while the lowest expression divergence has been observed in the brain.

The majority of genes with expression divergence in the brain exhibit a human specific upregulation (increased expression). This human specific upregulation has not been observed in the liver.

Parallel patterns of gene expression differences and protein divergence have been detected, suggesting that both types of changes have evolved in concert.

Genes expressed in testis, and especially those located on the $\mathrm{X}$ chromosome, display high expression and sequence divergence but reduced diversity in humans, indicating that genes involved in reproduction evolved under positive selection.

Adaptive evolution of human upstream regulatory regions I has been proven for the prodynorphin (PDYN) and the factor VII (F7) genes.

Nine cytogenetically detectable pericentric inversions and one fusion that gave rise to human chromosome 2 serve to distinguish PTR an HSA; no genes were disrupted at the breakpoints. Two inversions (chromosomes I and I8) were fixed in the human lineage. Insertions of 10 to $15 \mathrm{~kb}$ have given rise to a total of $\sim 32 \mathrm{Mb}$ of human-specific DNA sequence.

Insertions of $>15 \mathrm{~kb}$ gave rise to $\sim 8 \mathrm{Mb}$ of human-specific sequences.

Genomewide comparisons have indicated that some 40-45 Mb of lineage-specific sequence results from insertions/deletions resulting in copy number 2 differences between HSA and PTR. The number of Alu sequence insertions in HAS was $\sim 3.4$-fold higher than in PTR. A different set of Alu sequences has been amplified in both species, while the rate of LI element retrotranspositional activity has been relatively similar in HSA and PTR.

Direct genome comparisons revealed I,000 SVA retrotransposons specific to the human lineage and a comparable number of chimpanzee lineage-specific integrations.

The large number of lineage-specific transposon insertions in PTR and HAS could have had functional consequences with respect to gene expression or inactivation. 45 chimpanzee-specific endogenous retroviral element insertions and 73 human-specific insertions have been identified. 
Table I (Continued)

\begin{tabular}{|c|c|}
\hline Category & Results \\
\hline Microsatellite/RY-tract/Triplet repeat evolution & $\begin{array}{l}\text { Microsatellites, triplet-repeats, and RY-tracts tend to be longer in HSA than in PTR } \\
\text { suggesting that expansion-type mutations have occurred disproportionately in the } \\
\text { human lineage. }\end{array}$ \\
\hline $\begin{array}{l}\text { Submicroscopic structural divergence/segmental } \\
\text { duplications }\end{array}$ & $\begin{array}{l}33 \% \text { of segmental duplications }(26.5 \mathrm{Mb}) \text { are duplicated only in HSA; they map to at } \\
\text { least } 500 \text { distinct regions of average length } \sim 55 \mathrm{~kb} \text { and are distributed throughout the } \\
\text { genome. } \\
\text { There are many structural differences in subtelomeric regions of HSA compared to PTR. } \\
\text { Microinversions of }>\text { I kb up to several Mb contribute significantly to genome } \\
\text { divergence and (intraspecies) diversity. }\end{array}$ \\
\hline Human-specific genes/pseudogenes & $\begin{array}{l}\text { At least I } 80 \text { genes and partial gene sequences have become duplicated specifically in the } \\
\text { human genome. } \\
\text { Humans manifest a larger number of lineage-specific gene duplications than the great } \\
\text { apes; I } 34 \text { gene families have been identified with human lineage-specific gains including a } \\
\text { number of genes with brain-related functions. } \\
\text { I } 63 \text { human-specific retrotransposed gene copies have been identified. }\end{array}$ \\
\hline
\end{tabular}

Note: Reproduced with permission of the publisher from Kehrer-Sawatzki and Cooper. ${ }^{175}$

Abbreviations: HSA, Homo sapiens; PTR, Pan troglodytes.

it is being used for. All of this is factored in to the honest use of the statistics described above.

Such analyses have been performed. For example, Suter ${ }^{179}$ reported on the results of testing six drugs on animals and humans. Animals and humans shared 22 side effects. Animals incorrectly identified 48 side effects that did not in fact occur in humans, and the animals incorrectly missed 20 side effects that did occur in humans. This yields the following:

- $\mathrm{SN}=22 /(22+20)=0.52$

- $\mathrm{PPV}=22 /(22+48)=0.31$

A PPV of 0.31 does not qualify as predictive in medical science. Medical interventions require numbers as close to 1.0 as possible, at least in the $0.8-1.0$ range. However, sometimes the calculations are even easier. Zero vaccines have been efficacious in humans against HIV, while scores have shown efficacy in NHPs. ${ }^{101,180-183}$ The PPV here is obviously zero. The PPV is also zero for neuroprotectant drugs.

Two reviews examined drugs that proved to have toxicities so severe that they were withdrawn from the market.
In the first review, only 4 out of 24 toxicities correlated with animal data, and in the other review only 6 out of 114 clinical toxicities had animal correlates. ${ }^{184,185}$ Duyk states: "The villain in this story [of the attrition of drugs in development] is the inherent lack of predictability of our available models for complex biological processes and the inability of our current life science paradigm to provide an effective road map for improvement." 77

Monkeys were tested for the effects of the Alzheimer's vaccine $\mathrm{AN}-1792$ and the CD28 agonist TGN1412. The severe side effects seen in humans did not manifest in the monkeys. ${ }^{186}$ NHPs have also failed to qualify as predictive with regard to drugs that were teratogenic in humans. ${ }^{187,188}$ Genetic mutations that cause severe diseases in humans, like phenylketonuria and Sanfilippo syndrome, do not cause diseases in macaques. ${ }^{189,190}$ Cancer research using NHPs has been an unqualified failure. ${ }^{191}$

The above must be considered in light of the fact that two humans will not necessarily respond the same way to drugs

Table 2 Number of gene expression differences between brains of humans and chimpanzees

\begin{tabular}{|c|c|c|c|c|c|c|c|c|c|c|c|c|}
\hline \multirow[t]{2}{*}{ Region } & \multicolumn{6}{|c|}{ Humans } & \multicolumn{6}{|c|}{ Chimpanzees } \\
\hline & B & BR & PFC & PMC & PVC & $\overline{A C C}$ & $\overline{C N}$ & B & PFC & PVC & $A C C$ & $\mathrm{CN}$ \\
\hline $\mathrm{BR}$ & 4 & & & & & & & & & & & \\
\hline PFC & I & 5 & & & & & & 0 & & & & \\
\hline PMC & 23 & 3 & 38 & & & & & & & & & \\
\hline PVC & 21 & 77 & 37 & 23 & & & & 130 & 114 & & & \\
\hline $\mathrm{ACC}$ & 40 & 42 & 29 & 158 & 193 & & & 5 & 17 & 227 & & \\
\hline $\mathrm{CN}$ & 473 & 598 & 493 & 560 & 485 & 594 & & 601 & 557 & 710 & 548 & \\
\hline $\mathrm{CB}$ & 1327 & 1423 & 1414 & 1332 & 1017 & 1453 & 1601 & 1181 & 1205 & 892 & 1224 & 1320 \\
\hline
\end{tabular}

Note: Reproduced with permission of the publisher from Khaitovich et al, 2004. ${ }^{176}$

Abbreviations: B, Broca's area; BR, the homologous area to Broca's area in the right hemisphere; PFC, prefrontal cortex; PMC, premotor cortex; PVC, primary visual cortex; $A C C$, anterior cingulate cortex; $C N$, caudate nucleus; $C B$, cerebellum. 
Table 3 Gene expression differences in brains from humans and chimpanzees

\begin{tabular}{llllllll}
\hline Region & \multicolumn{2}{l}{ U95A array } & & \multicolumn{3}{l}{ U95A-E arrays } \\
\cline { 2 - 4 } & Detected & Changed & $\%$ & & Detected & Changed & $\%$ \\
\hline B & 4726 & 143 & 3 & 13716 & 685 & 5 \\
PFC & 4943 & 175 & 3.5 & & & \\
PVC & 4820 & 148 & 3.1 & & & \\
ACC & 5001 & 157 & 3.1 & $1408 I$ & 636 & 4.5 \\
CN & 4828 & 157 & 3.3 & 13693 & 735 & 5.4 \\
CB & 4915 & 268 & 5.5 & 15233 & 1186 & 7.8 \\
Combined & 5839 & 528 & 9 & 18516 & 1945 & 10.5 \\
\hline
\end{tabular}

Note: Reproduced with permission of the publisher from Khaitovich et al, 2004. ${ }^{172}$ Abbreviations: B, Broca's area; PFC, prefrontal cortex; PVC, primary visual cortex; $\mathrm{ACC}$, anterior cingulate cortex; $\mathrm{CN}$, caudate nucleus; $\mathrm{CB}$, cerebellum.

and disease. Physicians have known for decades that there were differences in response to drugs and disease between the sexes ${ }^{192-195}$ and among ethnic groups. ${ }^{196-203}$ Scientists have long known that different strains of rodents responded differently to perturbations. ${ }^{114,147,148,150,204-207}$ This realization, of intra-species differences, has led to a new concept and practice called "personalized medicine." $193,195-197,199,201,202$ Personalized medicine is the concept that each person, even a monozygotic twin, ${ }^{158,208-210}$ is genetically unique, and therefore medicines should be designed for the individual. This field finally abandons the notion of one-size-fits-all or one medicine for everyone and recognizes that diseases will also affect each person differently. This is the way medicine will be practiced in the future, and fortunately, personalized medicine is affecting medical care even now.

The US Food and Drug Administration warned on March 12,2010 that the blood thinner clopidogrel is not effective in some people. ${ }^{211}$ The reason being that some patients have a genetic makeup that will not allow clopidogrel to function as designed. Clopidogrel is converted by enzymes in the liver, especially CYP2C19, to another chemical that actually

\begin{tabular}{|c|c|c|c|}
\hline & & \multicolumn{2}{|c|}{ Gold standard } \\
\hline & & GS+ & GS- \\
\hline \multirow{2}{*}{ Test } & T+ & TP & FP \\
\cline { 2 - 4 } & T- & FN & TN \\
\hline \multicolumn{2}{|l}{} \\
T+ = Test positive \\
T- = Test negative \\
T = True \\
F = False \\
P = Positive \\
N = Negative \\
GS+ = Gold standard positive \\
GS- = Gold standard negative \\
\end{tabular}

Figure 2 Table for comparing test with gold standard.

\begin{tabular}{|l|}
\hline Sensitivity $=$ TP/TP + FN \\
\hline Specificity $=$ TN/FP + TN \\
\hline Positive predictive value $=$ TP $/ T P+$ FP \\
\hline Negative predictive value $=$ TN/FN + TN \\
\hline
\end{tabular}

Figure 3 Calculating sensitivity, specificity, positive predictive value, and negative predictive value.

Abbreviations: $\mathrm{FN}$, false negative; FP, false positive; TN, true negative; TP, true positive.

does the work of preventing blood clots. If the patient has two copies of a variant of the gene coding for CYP2C19, then the drug will not be converted into the active chemical. As many as $14 \%$ of Chinese patients have this variant. However, many other patients have one copy of the variant thus exposing them to risks as well. A genetic test and a routine blood test are both available to determine whether the patient has the genetic makeup that predisposes to the ineffectiveness and to determine whether clopidogrel is having the desired effect.

Currently, gene-based tests exist to:

- Determine the dose of 6-mercaptopurine.

- Determine the dose for warfarin.

- Determine whether codeine can be used in a patient.

- Determine whether tamoxifen can be used in a patient.

- Design treatment for various cancers including breast and colon. $^{212}$

The differences in human response to perturbations such as drugs and disease can also be explained by the same science discussed above. The fact that two complex systems exhibit small differences in initial conditions - be that difference in genes or epigenetics - or other aspects of a complex system means that the same perturbation can result in dramatically different outcomes. The empirical evidence agrees with the theoretical concerns from complexity science and evolutionary biology. The fact that the Bateson Review ignored the empirical evidence regarding the use of NHPs in research reinforces the present authors' position that the review cannot be interpreted as serious science.

\section{Conclusion}

The following conclusions can be drawn regarding the Bateson Review.

1. It does not fulfill the criteria of a formal systematic review, as defined by the Cochrane Collaboration. ${ }^{23}$ 
2. It does not fulfill the criteria of a review article, based on the National Library of Medicine definition. ${ }^{24}$

3. It is not a peer-reviewed document.

4. It ignores the current scientific understanding of evolved complex systems. In order for the Review to be considered scientific, it must consider the current science that relates to the use of NHPs in research. The use of one complex system to predict outcomes for another is scientifically suspect, as explained above. Moreover, comprehension of the fundamentals of evolutionary biology also profoundly impacts on what society can and cannot expect from studying NHPs in order to find treatments for humans. Since the Bateson Review ignores these subjects, the review cannot be considered a scientific examination of the issue. As it is not a scientifically competent exam, neither can it be considered competent in any other area, such as ethics.

5. It ignores the current empirical evidence and review articles relevant to the use of animals in basic and applied research. The knowledge from complexity science and evolutionary biology can be viewed as the theory that places the empirical evidence in context. However, having ignored the theory, the Review then ignores the empirical evidence as outlined here.

6. It resembles an opinion piece written by a group of people with a vested interest in what they are evaluating.

The scientific inadequacy of the Bateson Review notwithstanding, there is a larger issue here. Using NHPs to predict human response is not an example of applying a set of well-established reductionism-based scientific principles to a simple system, as occurs with Newtonian physics. The Kingdom Animalia is composed of living complex adaptive systems that have evolved with different trajectories. This has major implications for interspecies extrapolation. While many of the components present in members of Animalia may be conserved, the differences in initial conditions, presence of emergent properties, the fact that interactions occur on different levels, in addition to the presence of add-ons, diminishes the probability of interspecies extrapolation of medically relevant knowledge to a number unacceptable in medical science. There is no evolutionary basis to the expectation that phylogenetic closeness will ensure similarities in the response to drugs vis-à-vis efficacy, bioavailability, clearance, metabolism, and toxicity, or in the pathophysiology of disease. Different genes and different mechanisms can cause, in animals, what appears to be the human condition under study.

All of this must be considered in light of the fact that even two closely related humans do not respond the same way to drugs and disease. If humans are unreliable predictors for other humans, the probability that an animal species, even an NHP, will fulfill this role is essentially zero. A proper understanding of complexity science and evolutionary biology precludes the necessity of a case-by-case analysis of research using NHPs.

Based on current scientific understanding of complex systems and evolutionary biology, the premises underlying the use of NHPs in biomedical research and testing are not viable. The legal requirements for drug testing using NHPs and the permission granted by society for scientists to use NHPs in biomedical research are both based on the myth of direct extrapolation between species, which in turn is based on the myth of creationism. Even if research that uses NHPs claimed to be basic research, the results from such research are so meager that, were society to be aware of this, they would likely not allow the research. An honest discussion of the ethics and legal requirements can only take place after the relevant science has been used to inform society of the pertinent facts. This has not been done. Were society to be aware of the limitations of using NHPs in research, as outlined above, the authors doubt it would allow such use, as society would find such use unethical.

There are profound ethical and legal implications to the above. Government regulatory authorities, advocates for animals, society in general, and funding agencies in particular do not need more monographs masquerading as science. As discussed in this paper, the current science relevant to using NHPs in biomedical research does not allow claims for likely human benefit to be made. While comparative research will almost always result in more knowledge, there is a vast difference between that type of knowledge and the kind that benefits humans suffering from disease.

\section{Disclosure}

The authors report no conflicts of interest in this work. The position presented in this article represents that of the authors and not that of the University of California, San Diego.

All authors are officers of Americans for Medical Advancement (AFMA), a US not-for-profit organization. None receive compensation from AFMA. AFMA is not a pro-animal organization nor a pro-use organization. AFMA addresses only the scientific use of animals in science and research and acknowledges that animals can be successfully used in seven areas. These are areas of research and science where animal use has been shown scientifically valid. AFMA questions the use of animals as models to predict human response to drugs and disease. For more on the AFMA's position, please see the question "AFMA is frequently identified as an animal rights group. Why?"213 on the AFMA website and the AFMA's website in general. ${ }^{214}$ 


\section{References}

1. Hau J, Schapiro S. Non-human primates in biomedical research. Scand J Lab Anim Sci. 2006;33(1):9-12.

2. Carlsson HE, Schapiro SJ, Farah I, Hau J. Use of primates in research: a global overview. Am J Primatol. 2004;63(4):225-237.

3. Honess PE, Johnson PJ, Wolfensohn SE. A study of behavioural responses of non-human primates to air transport and re-housing. Lab Anim. 2004;38(2):119-132.

4. Malik I. Consequences of export and trapping of monkeys. Primate Rep. 1992;34:5-12.

5. Southwick C, Siddiqi M. Status, conservation and management of primates in India. In: Gupta AK, editor. Non-Human Primates of India, ENVIS Bulletin: Wildlife and Protected Areas. Vol 1(1). Dehradun: Wildl Inst India; 2001:81-91.

6. Gad S. Preface. In: Gad S, editor. Animal Models in Toxicology. Boca Rotan: CRC Press; 2007:1-18.

7. Thirlway H. US and UK primate imports. International Primate Protection League (IPPL) News. 2009;36(1):2009;14-16. Available from: http://www.ippl.org/newsletter/2000s/IPPL-News-May-2009. pdf. Accessed September 3, 2011.

8. IPPL. US primate imports spike [web page on the Internet]. Summerville, SC: IPPL; 2007. Available from: https://secure.ippl.org/ newsletter/2000s/101_v34_n1_2007-2004.pdf\#page=8 (go to page 8). Accessed October 27, 2011.

9. "Sharon." US 2010 primate imports increase slightly over 2009 figures. [web page on the Internet]. Summerville, SC: IPPL; September 16, 2011. Available from: https://secure.ippl.org/gibbon-wp/u-s-2010primate-imports-increase-slightly/. Accessed September 3, 2011.

10. Convention on International Trade in Endangered Species of Wild Fauna and Flora (CITES). Experts concerned about level of trade in snake skins used in luxury products: long-tailed macaque used in biomedical research, sturgeons, seahorses and shark-fishing regulations also under review [press release]. Geneva: CITES; July 22, 2011. Available from: http://www.cites.org/eng/ news/press/2011/20110722_AC25.php. Accessed August 30, 2011.

11. Shanks N, Greek R. Animal Models in Light of Evolution. Boca Raton: Brown Walker; 2009.

12. Shanks N, Greek R, Greek J. Are animal models predictive for humans? Philos Ethics Humanit Med. 2009;4(1):2.

13. Scientific Committee on Health and Environmental Risks (SCHER). The Need for Non-Human Primates in Biomedical Research, Production and Testing of Products and Devices. Brussels: European Commission; 2009. Available from: http://ec.europa.eu/environment/chemicals/ lab_animals/pdf/scher_o_110.pdf. Accessed August 30, 2011.

14. Greek R, Greek J. Is the use of sentient animals in basic research justifiable? Philos Ethics Humanit Med. 2010;5:14.

15. Greek R, Pound P. Animal studies and HIV research. BMJ. 2002; 324(7331):236-237.

16. Greek R, Shanks N. FAQs About the Use of Animals in Science: A Handbook for the Scientifically Perplexed. New York: University Press of America; 2009.

17. Shanks N, Greek R, Nobis N, Greek J. Animals and medicine: do animal experiments predict human response? Skeptic. 2007;13(3):44-51.

18. Knight A. The poor contribution of chimpanzee experiments to biomedical progress. J Appl Anim Welf Sci. 2007;10(4):281-308.

19. Knight A. The beginning of the end for chimpanzee experiments? Philos Ethics Humanit Med. 2008;3:16.

20. Knight A, Bailey J, Balcombe J. Animal carcinogenicity studies: 1. Poor human predictivity. Altern Lab Anim. 2006;34(1):19-27.

21. Bateson P. Review of Research Using Non-Human Primates. 2011. Available from: http://www.bbsrc.ac.uk/web/FILES/Reviews/reviewresearch-using-nhps.pdf. Accessed October 21, 2011.

22. Weatherall D. The Use of Nonhuman Primates in Research. London: Academy of Medical Sciences; 2006.

23. The Cochrane Collaboration. Cochrane Handbook for Systematic Reviews of Interventions. Oxford: The Cochrane Collaboration; 2011. Available from: http://www.cochrane.org/training/cochrane-handbook. Accessed August 30, 2011.
24. Van Buskirk NE. The review article in MEDLINE: ambiguity of definition and implications for online searchers. Bull Med Libr Assoc. 1984;72(4):349-352. Available from: http://www.ncbi.nlm.nih. gov/pmc/articles/PMC227511/pdf/mlab00064-0039.pdf. Accessed August 30, 2011.

25. Leydesdorff L, Opthof T. Scopus's source normalized impact per paper (SNIP) versus a journal impact factor based on fractional counting of citations. J Am Soc Inf Sci Technol. 2010;61(11):2365-2369.

26. Honey RC, Bateson P. Stimulus comparison and perceptual learning: further evidence and evaluation from an imprinting procedure. $Q J \operatorname{Exp}$ Psychol B. 1996;49(3):259-269.

27. Honey RC, Bateson P, Horn G. The role of stimulus comparison in perceptual learning: an investigation with the domestic chick. $Q J \operatorname{Exp}$ Psychol B. Feb 1994;47(1):83-103.

28. McCabe BJ, Cipolla-Neto J, Horn G, Bateson P. Amnesic effects of bilateral lesions placed in the hyperstriatum ventrale of the chick after imprinting. Exp Brain Res. 1982;48(1):13-21.

29. McCabe BJ, Horn G, Bateson PP. Effects of restricted lesions of the chick forebrain on the acquisition of filial preferences during imprinting. Brain Res. 1981;205(1):29-37.

30. Bradley P, Horn G, Bateson P. Imprinting. An electron microscopic study of chick hyperstriatum ventrale. Exp Brain Res. 1981;41(2): 115-120.

31. Horn G, McCabe BJ, Bateson PP. An autoradiographic study of the chick brain after imprinting. Brain Res. 1979;168(2): 361-373.

32. Bateson PP, Horn G, McCabe BJ. Imprinting: the effect of partial ablation of the medial hyperstriatum ventrale of the chick [proceedings]. J Physiol. 1978;285:23P.

33. Bateson PP, Horn G, McCabe BJ. Imprinting and the incorporation of uracil in the chick brain: a radioautographic study [proceedings]. J Physiol. 1978;275:70P.

34. Hambley JW, Haywood J, Rose SP, Bateson PP. Effects of imprinting on lysine uptake and incorporation into protein in chick brain. J Neurobiol. 1977;8(2):109-118.

35. Haywood J, Rose SP, Bateson P. Changes in chick brain RNA polymerase associated with an imprinting procedure. Brain Res. 1975;92(2):227-235.

36. Bateson PP, Horn G, Rose SP. Imprinting: correlations between behaviour and incorporation of (14-C) uracil into chick brain. Brain Res. 1975;84(2):207-220.

37. Bateson PP, Rose SP, Horn G. Imprinting: lasting effects on uracil incorporation into chick brain. Science. 1973;181(99):576-578.

38. Bateson PP, Horn G, Rose SP. Effects of early experience on regional incorporation of precursors into RNA and protein in the chick brain. Brain Res. 1972;39(2):449-465.

39. Horn G, Horn AL, Bateson PP, Rose SP. Effects of imprinting on uracil incorporation into brain RNA in the "split-brain" chick. Nature. 1971;229(5280):131-132.

40. Rushworth MF, Johansen-Berg H, Young SA. Parietal cortex and spatial-postural transformation during arm movements. J Neurophysiol. 1998;79(1):478-482.

41. Mellanby J, Johansen-Berg H, Leyland R, Milward AJ. The effects of tetanus toxin-induced limbic epilepsy on the exploratory response to novelty in the rat. Epilepsia. 1999;40(8):1058-1061.

42. Mars RB, Jbabdi S, Sallet J, et al. Diffusion-weighted imaging tractography-based parcellation of the human parietal cortex and comparison with human and macaque resting-state functional connectivity. J Neurosci. 2011;31(11):4087-4100.

43. Klein JC, Rushworth MF, Behrens TE, et al. Topography of connections between human prefrontal cortex and mediodorsal thalamus studied with diffusion tractography. Neuroimage. 2010;51(2):555-564.

44. Croxson PL, Johansen-Berg H, Behrens TE, et al. Quantitative investigation of connections of the prefrontal cortex in the human and macaque using probabilistic diffusion tractography. $J$ Neurosci. 2005;25(39):8854-8866. 
45. Freidlin RZ, Ozarslan E, Komlosh ME, et al. Parsimonious model selection for tissue segmentation and classification applications: a study using simulated and experimental DTI data. IEEE Trans Med Imaging. 2007;26(11):1576-1584.

46. Pomeroy IM, Jordan EK, Frank JA, Matthews PM, Esiri MM. Diffuse cortical atrophy in a marmoset model of multiple sclerosis. Neurosci Lett. 2008;437(2):121-124.

47. Pomeroy IM, Matthews PM, Frank JA, Jordan EK, Esiri MM. Demyelinated neocortical lesions in marmoset autoimmune encephalomyelitis mimic those in multiple sclerosis. Brain. 2005;128 (Pt 11):2713-2721.

48. Ramnani N, Behrens TE, Johansen-Berg H, et al. The evolution of prefrontal inputs to the cortico-pontine system: diffusion imaging evidence from Macaque monkeys and humans. Cereb Cortex 2006;16(6):811-818.

49. Perrett DI, Smith PA, Mistlin AJ, et al. Visual analysis of body movements by neurones in the temporal cortex of the macaque monkey: a preliminary report. Behav Brain Res. 1985;16(2-3):153-170.

50. Perrett DI, Smith PA, Potter DD, et al. Visual cells in the temporal cortex sensitive to face view and gaze direction. Proc R Soc Lond B Biol Sci. 1985;223(1232):293-317.

51. Cranage M, Sharpe S, Herrera C, et al. Prevention of SIV rectal transmission and priming of $\mathrm{T}$ cell responses in macaques after local pre-exposure application of tenofovir gel. PLoS Med. 2008;5(8):e157; discussion e157.

52. Cranage MP, Fraser CA, Cope A, et al. Antibody responses after intravaginal immunisation with trimeric HIV-1 CN54 clade C gp140 in Carbopol gel are augmented by systemic priming or boosting with an adjuvanted formulation. Vaccine. 2011;29(7):1421-1430.

53. Curran RM, Donnelly L, Morrow RJ, et al. Vaginal delivery of the recombinant HIV-1 clade-C trimeric gp140 envelope protein CN54gp140 within novel rheologically structured vehicles elicits specific immune responses. Vaccine. 2009;27(48):6791-6798.

54. Veazey RS, Klasse PJ, Schader SM, et al. Protection of macaques from vaginal SHIV challenge by vaginally delivered inhibitors of virus-cell fusion. Nature. 2005;438(7064):99-102

55. Wallace GS, Cheng-Mayer C, Schito ML, et al. Human immunodeficiency virus type 1 nucleocapsid inhibitors impede trans infection in cellular and explant models and protect nonhuman primates from infection. J Virol. 2009;83(18):9175-9182.

56. Wegmann F, Krashias G, Luhn K, et al. A novel strategy for inducing enhanced mucosal HIV-1 antibody responses in an anti-inflammatory environment. PLoS ONE. 2011;6(1):e15861.

57. Crano WD. Attitude strength and vested interest. In: Petty RE, Krosnick JA, editors. Attitude Strength: Antecedents and Consequences. Mahwah, NJ: Erlbaum; 1995:131-158.

58. Biotechnology and Biological Sciences Research Council (BBSRC) Biomedical research funders respond to the Review of Research Using Non-Human Primates [web page on the Internet]. Swindon: BBSRC; July 27, 2011. Available from: http://www.bbsrc.ac.uk/news/ policy/2011/110727-pr-response-review-research-using-nhps.aspx. Accessed August 31, 2011.

59. politics.co.uk. RSPCA reaction to the review of using non-human primates. politics.co.uk; July 27, 2011. Available from: http://www. politics.co.uk/opinion-formers/rspca-royal-society-for-the-preventionof-cruelty-to-animals/article/rspca-reaction-to-the-review-of-usingnon-human-primates. Accessed October 27, 2011.

60. Dr Hadwen Trust for Humane Research. Dr Hadwen Trust welcomes Bateson report but calls for annual review [press release]. Hitchin: Dr Hadwen Trust for Humane Research; July 29, 2011. Available from: http://www.drhadwentrust.org/downloads/press-releases/ DHTpressrelease-responsetoBatesonnhpreview-29.07.11.pdf. Accessed August 31, 2011.

61. Jha A. One in ten research projects using monkeys has no benefit, finds review. Guardian. July 27, 2011. Available from: http://www.guardian. co.uk/science/2011/jul/27/research-projects-monkeys-benefit. Accessed August 31, 2011.
62. Callaway E. Primate research gets provisional thumbs-up in UK review. newsblog. July 27, 2011. Available from: http://blogs.nature. com/news/2011/07/primate_research_gets_provisio.html. Accessed August 31, 2011.

63. Organisation for Economic Cooperation and Development (OECD). The Measurement of Scientific and Technical Activities: Proposed Standard Practice for Surveys of Research and Development. Paris: OECD; 1963.

64. Carmichael M, Begley S. Desperately seeking cures. Newsweek. May 14, 2010. Available from: http://www.newsweek.com/ id/238078? obref=obinsite. Accessed May 31, 2010.

65. Editorial. Hope in translation. Nature. 2010;467(7315):499.

66. Rosenberg RN. Translating biomedical research to the bedside: a national crisis and a call to action. JAMA. 2003;289(10): 1305-1306.

67. Pound P, Ebrahim S, Sandercock P, Bracken MB, Roberts I Where is the evidence that animal research benefits humans? BMJ. 2004;328(7438):514-517.

68. Ioannidis JP. Materializing research promises: opportunities, priorities and conflicts in translational medicine. J Transl Med. 2004;2(1):5.

69. Begley S. Coddling human guinea pigs. Newsweek. 2008;152 (7-8): 14 .

70. Steinman R, Szalavitz M. Patients have been too patient with basic research. Cerebrum. 2002;4:4

71. Editorial. Cancer drugs: remedy required. Nat Med. 2011;17(3) 231-231.

72. Contopoulos-Ioannidis DG, Ntzani E, Ioannidis JP. Translation of highly promising basic science research into clinical applications. Am J Med. 2003;114(6):477-484.

73. Crowley WF Jr. Translation of basic research into useful treatments: how often does it occur? Am J Med. 2003;114(6):503-505.

74. Butler D. Translational research: crossing the valley of death. Nature. 2008;453(7197):840-842.

75. Ledford H. Translational research: the full cycle. Nature. 2008;453(7197): 843-845.

76. Marincola FM. In support of descriptive studies; relevance to translational research. J Transl Med. 2007;5:21.

77. Duyk G. Attrition and translation. Science. 2003;302(5645):603-605.

78. Rothwell PM. Funding for practice-oriented clinical research. Lancet. 2006;368(9532):262-266.

79. Rothwell PM. Medical academia is failing patients and clinicians. $B M J$. 2006;332(7546):863-864.

80. Fenster A. A TRENDS guide to imaging technologies. Trends Biotechnol. 2002;20(8):S1-S2.

81. Fuchs VR, Sox HC Jr. Physicians' views of the relative importance of thirty medical innovations. Health Aff (Millwood). 2001;20(5): $30-42$.

82. Grant J, Cottrell R, Cluzeau F, Fawcett G. Evaluating "payback" on biomedical research from papers cited in clinical guidelines: applied bibliometric study. BMJ. 2000;320(7242):1107-1111.

83. Grant J, Green L, Mason B. From Bedside to Bench: Comroe and Dripps revisited. Health Economics Research Group research report. Middlesex: Brunel University; Aug 2003.

84. Grant J, Green L, Mason B. Basic research and health: a reassessment of the scientific basis for the support of biomedical science. Res Eval. 2003;12(3):217-224.

85. Grant J, Hanney S, Buxton M. Academic medicine: time for reinvention: research needs researching. BMJ. 2004;328(7430):48; discussion 49.

86. Comroe JH Jr, Dripps RD. Scientific basis for the support of biomedical science. Science. 1976;192(4235):105-111.

87. Smith R. Comroe and Dripps revisited. Br Med J (Clin Res Ed) 1987;295(6610):1404-1407.

88. Cushman DW, Ondetti MA. Design of angiotensin converting enzyme inhibitors. Nat Med. 1999;5(10):1110-1113.

89. Lindl T, Voelkel M, Kolar R. Animal experiments in biomedical research. An evaluation of the clinical relevance of approved animal experimental projects. ALTEX. 2005;22(3):143-151. 
90. Hackam DG, Redelmeier DA. Translation of research evidence from animals to humans. JAMA. 2006;296(14):1731-1732.

91. Kaste M. Use of animal models has not contributed to development of acute stroke therapies: pro. Stroke. 2005;36(10):2323-2324.

92. Johnston SC. Translation: case study in failure. Ann Neurol. 2006;59(3): 447-448.

93. Dennis C. Cancer: off by a whisker. Nature. 2006;442(7104): 739-741.

94. Cimons M, Getlin J, Maugh TH II. Cancer drugs face long road from mice to men. Los Angeles Times. May 6, 1998. Available from: http:// articles.latimes.com/1998/may/06/news/mn-46795. Accessed November 8, 2010.

95. Hanash S. Integrated global profiling of cancer. Nat Rev Cancer. 2004;4(8):638-644.

96. Editors. Nic Jones. Nat Rev Drug Discov. 2011;10(4):252-252.

97. Caponigro G, Sellers WR. Advances in the preclinical testing of cancer therapeutic hypotheses. Nat Rev Drug Discov. 2011;10(3):179-187.

98. Leaf C. Why we are losing the war on cancer. Fortune. March 9, 2004: 77-92.

99. Zielinska E. Building a better mouse. Scientist. 2010;24(4):34-38.

100. Enna SJ, Williams M. Defining the role of pharmacology in the emerging world of translational research. Adv Pharmacol. 2009;57:1-30.

101. Editorial. Cold shower for AIDS vaccines. Nat Med. 2007;13(12): $1389-1390$.

102. Bailey J. An assessment of the role of chimpanzees in AIDS vaccine research. Altern Lab Anim. 2008;36(4):381-428.

103. Geerts H. Of mice and men: bridging the translational disconnect in CNS drug discovery. CNS Drugs. 2009;23(11):915-926.

104. Munos B. Lessons from 60 years of pharmaceutical innovation. Nat Rev Drug Discov. 2009;8(12):959-968.

105. Giri S, Bader A. Improved preclinical safety assessment using microBAL devices: the potential impact on human discovery and drug attrition. Drug Discov Today. 2011;16(9/10):382-397.

106. Collins FS. Reengineering translational science: the time is right. Sci Transl Med. 2011;3(90):90 $\mathrm{cm} 17$.

107. Committee on Applications of Toxicogenomics to Cross-Species Extrapolation, Committee on Emerging Issues and Data on Environmental Contaminants, National Research Council. Application of Toxicogenomics to Cross-Species Extrapolation: A Report of a Workshop. Washington, DC: National Academy of Sciences; 2005.

108. Sarkar SK. Molecular imaging approaches. Drug Discov World. 2009;(Fall):33-38.

109. Littman BH, Williams SA. The ultimate model organism: progress in experimental medicine. Nat Rev Drug Discov. 2005;4(8):631-638.

110. Chabner BA, Roberts TG Jr. Timeline: Chemotherapy and the war on cancer. Nat Rev Cancer. 2005;5(1):65-72.

111. Editorial. The time is now. Nat Rev Drug Discov. 2005;4(8):613.

112. Chapman AR. Addressing the ethical challenges of first-in-human trials. J Clinic Res Bioeth. 2011;2(4):113.

113. Palfreyman MG, Charles V, Blander J. The importance of using human-based models in gene and drug discovery. Drug Discov World. 2002;(Fall):33-40.

114. Dixit R, Boelsterli U. Healthy animals and animal models of human disease(s) in safety assessment of human pharmaceuticals, including therapeutic antibodies. Drug Discov Today. 2007;12(7-8): 336-342.

115. Editors. In this issue. Nat Rev Drug Discov. 2011;10(4):239-239.

116. Leslie M. Biomedical research. Immunology uncaged. Science. 2010;327(5973):1573.

117. Dorsey ER, de Roulet J, Thompson JP, et al. Funding of US biomedical research, 2003-2008. JAMA. 2010;303(2):137-143.

118. Boat TF. Insights from trends in biomedical research funding. JAMA. 2010;303(2):170-171.

119. Translational research: getting the message across. Nature. 2008; 453(7197):839.

120. Begley S. Financial obstacles help keep doctors from patient research. Wall St J. May 2, 2003.
121. Begley S. Physician-researchers needed to get cures out of rat's cage. Wall St J. April 25, 2003.

122. Begley S. Why nonprofits fund for-profit researchers. Wall St J. January 26, 2007.

123. LaFollette $\mathrm{H}$, Shanks $\mathrm{N}$. Animal experimentation: the legacy of Claude Bernard. Intl Studies Philosophy Sci. 1994;8(3):195-210.

124. Bernard C. An Introduction to the Study of Experimental Medicine. New York: Dover; 1957 (1865). (Specifically see pp 15, 24, 33, 111, 117-126, 138-139, 146-148, 180.)

125. Elliot P. Vivisection and the emergence of experimental medicine in nineteenth century France. In: Rupke N, editor. Vivisection in Historical Perspective. New York: Croom Helm; 1987:48-77.

126. Ahn AC, Tewari M, Poon CS, Phillips RS. The limits of reductionism in medicine: could systems biology offer an alternative? PLoS Med. 2006;3(6):e208.

127. Jura J, Wegrzyn P, Koj A. Regulatory mechanisms of gene expression: complexity with elements of deterministic chaos. Acta Biochim Pol. 2006;53(1):1-10.

128. Van Regenmortel MHV. Biological complexity emerges from the ashes of genetic reductionism. J Mol Recognit. 2004;17(3):145-148.

129. Van Regenmortel MHV. Reductionism and complexity in molecular biology. Scientists now have the tools to unravel biological and overcome the limitations of reductionism. EMBO Rep. 2004;5(11): 1016-1020.

130. Schadt EE, Sachs A, Friend S. Embracing complexity, inching closer to reality. Sci STKE. 2005;2005(295):pe40.

131. Hayden EC. Human genome at ten: life is complicated. Nature. 2010; 464(7289):664-667.

132. Ottino JM. Engineering complex systems. Nature. 2004; 427(6973):399.

133. Vicsek T. The bigger picture. Nature. 2002;418(6894):131.

134. Monte J, Liu M, Sheya A, Kitami T. Definitions, Measures, and Models of Robustness in Gene Regulatory Network: Report of Research Work for CSSS05. 2005. Available from: http://citeseerx.ist.psu.edu/viewdoc/download?doi=10.1.1.89.1604\&rep=rep1\&type=pdf. Accessed October 27, 2011.

135. Grove AS. Efficiency in the health care industries: a view from the outside. JAMA. 2005;294(4):490-492.

136. Fell D. Understanding the Control of Metabolism. Volume 1. 1st ed. London: Portland Press; 1996.

137. Mayr M. Metabolomics. Circ Cardiovasc Genet. 2008;1(1):58-65.

138. Herzig M, Christofori G. Recent advances in cancer research: mouse models of tumorigenesis. Biochim Biophys Acta. 2002; 1602(2):97-113.

139. Carroll SB. Whatever doesn't kill some animals can make them deadly. New York Times. December 21, 2009. Available from: http://www.nytimes.com/2009/12/22/science/22creature. $\mathrm{html}$ ?emc=eta1\&pagewanted=print. Accessed August 2, 2011.

140. Horrobin DF. Modern biomedical research: an internally self-consistent universe with little contact with medical reality? Nat Rev Drug Discov. 2003;2(2):151-154.

141. Hunter K, Welch DR, Liu ET. Genetic background is an important determinant of metastatic potential. Nat Genet. 2003;34(1):23-24; author reply 25 .

142. Hunter KW, Broman KW, Voyer TL, et al. Predisposition to efficient mammary tumor metastatic progression is linked to the breast cancer metastasis suppressor gene Brms1. Cancer Res. 2001;61(24):8866-8872.

143. Ingram DK, Jucker M. Developing mouse models of aging: a consideration of strain differences in age-related behavioral and neural parameters. Neurobiol Aging. 1999;20(2):137-145.

144. Lifsted T, Le Voyer T, Williams M, et al. Identification of inbred mouse strains harboring genetic modifiers of mammary tumor age of onset and metastatic progression. Int J Cancer. 1998;77(4): 640-644.

145. Miklos GLG. The human cancer genome project - one more misstep in the war on cancer. Nat Biotechnol. 2005;23(5):535-537. 
146. Ioannidis JP. An epidemic of false claims. Competition and conflicts of interest distort too many medical findings. Sci Am. 2011;304(6):16.

147. Nijhout HF. The importance of context in genetics. Sci Am. 2003; 91(5):416-423.

148. Pearson H. Surviving a knockout blow. Nature. 2002;415(6867):8-9.

149. Raineri I, Carlson EJ, Gacayan R, et al. Strain-dependent high-level expression of a transgene for manganese superoxide dismutase is associated with growth retardation and decreased fertility. Free Radic Biol Med. 2001;31(8):1018-1030.

150. Regenberg A, Mathews DJ, Blass DM, et al. The role of animal models in evaluating reasonable safety and efficacy for human trials of cell-based interventions for neurologic conditions. J Cereb Blood Flow Metab. 2009;29(1):1-9.

151. Rohan RM, Fernandez A, Udagawa T, Yuan J, D'Amato RJ. Genetic heterogeneity of angiogenesis in mice. FASEB J. 2000;14(7):871-876.

152. Threadgill DW, Dlugosz AA, Hansen LA, et al. Targeted disruption of mouse EGF receptor: effect of genetic background on mutant phenotype. Science. 1995;269(5221):230-234.

153. Viluksela M, Duong TV, Stahl BU, Li X, Tuomisto J, Rozman KK. Toxicokinetics of 2,3,7,8-tetrachlorodibenzo-p-dioxin (TCDD) in two substrains of male Long-Evans rats after intravenous injection. Fundam Appl Toxicol. 1996;31(2):184-191.

154. Jones GL, Sang E, Goddard C, et al. A functional analysis of mouse models of cardiac disease through metabolic profiling. $J$ Biol Chem 2005;280(9):7530-7539.

155. Bendall JK, Heymes C, Wright TJ, et al. Strain-dependent variation in vascular responses to nitric oxide in the isolated murine heart. $J \mathrm{Mol}$ Cell Cardiol. 2002;34(10):1325-1333.

156. Paigen B, Morrow A, Brandon C, Mitchell D, Holmes P. Variation in susceptibility to atherosclerosis among inbred strains of mice. Atherosclerosis. 1985;57(1):65-73.

157. Linder CC. The influence of genetic background on spontaneous and genetically engineered mouse models of complex diseases. Lab Anim (NY). 2001;30(5):34-39.

158. von Herrath M, Nepom GT. Remodeling rodent models to mimic human type 1 diabetes. Eur J Immunol. 2009;39(8):2049-2054.

159. Dowell RD, Ryan O, Jansen A, et al. Genotype to phenotype: a complex problem. Science. 2010;328(5977):469.

160. Agarwal S, Moorchung N. Modifier genes and oligogenic disease. J Nippon Med Sch. 2005;72(6):326-334.

161. Gerhart J, Kirschner M. The theory of facilitated variation. In: Avise JC, Ayala FJ, editors. In the Light of Evolution: Volume 1. Adaptation and Complex Design. Washington, DC: National Academy of Sciences; 2007:45-64.

162. Kirschner MW, Gerhart JC. The Plausibility of Life. New Haven: Yale University Press; 2006.

163. PaiAA, Bell JT, Marioni JC, Pritchard JK, GiladY. A genome-wide study of DNA methylation patterns and gene expression levels in multiple human and chimpanzee tissues. PLoS Genet. 2011;7(2):e1001316.

164. Ptashne M, Gann A. Genes and Signals. New York: Cold Spring Harbor Laboratory Press; 2002.

165. Pennisi E. Searching for the genome's second code. Science. 2004;306(5696):632-635.

166. Morley M, Molony CM, Weber TM, et al. Genetic analysis of genome-wide variation in human gene expression. Nature. 2004;430(7001):743-747.

167. Rosenberg NA, Pritchard JK, Weber JL, et al. Genetic structure of human populations. Science. 2002;298(5602):2381-2385.

168. Storey JD, Madeoy J, Strout JL, Wurfel M, Ronald J, Akey JM. Gene-expression variation within and among human populations. Am J Hum Genet. 2007;80(3):502-509.

169. Zhang W, Duan S, Kistner EO, et al. Evaluation of genetic variation contributing to differences in gene expression between populations. Am J Hum Genet. 2008;82(3):631-640.

170. Pritchard C, Coil D, Hawley S, Hsu L, Nelson PS. The contributions of normal variation and genetic background to mammalian gene expression. Genome Biol. 2006;7(3):R26.
171. Rifkin SA, Kim J, White KP. Evolution of gene expression in the Drosophila melanogaster subgroup. Nat Genet. 2003;33(2):138-144.

172. Sandberg R, Yasuda R, Pankratz DG, et al. Regional and strain-specific gene expression mapping in the adult mouse brain. Proc Natl Acad Sci USA. 2000;97(20):11038-11043.

173. Suzuki Y, Nakayama M. Differential profiles of genes expressed in neonatal brain of $129 \mathrm{X} 1 / \mathrm{SvJ}$ and $\mathrm{C} 57 \mathrm{BL} / 6 \mathrm{~J}$ mice: a database to aid in analyzing DNA microarrays using nonisogenic gene-targeted mice. DNA Res. 2003;10(6):263-275.

174. Marvanova M, Menager J, Bezard E, Bontrop RE, Pradier L, Wong G. Microarray analysis of nonhuman primates: validation of experimental models in neurological disorders. FASEB J. May 2003;17(8):929-931.

175. Kehrer-Sawatzki H, Cooper DN. Understanding the recent evolution of the human genome: insights from human-chimpanzee genome comparisons. Hum Mutat. 2007;28(2):99-130.

176. Khaitovich P, Muetzel B, She X, et al. Regional patterns of gene expression in human and chimpanzee brains. Genome Res. 2004;14(8):1462-1473.

177. LaFollette H, Shanks N. Brute Science: Dilemmas of Animal ExperiMentation. London and New York: Routledge; 1996.

178. Giles J. Animal experiments under fire for poor design. Nature. 2006;444(7122):981

179. Suter K. What can be learned from case studies? The company approach. In: Lumley C, Walker S, editors. Animal Toxicity Studies: Their Relevance for man. Lancaster: Quay; 1990:71-78.

180. Thomas C, Moridani M. Interindividual variations in the efficacy and toxicity of vaccines. Toxicology. 2010;278(2):204-210.

181. Letvin NL. Virology. Moving forward in HIV vaccine development. Science. 2009;326(5957):1196-1198.

182. Morrow MP, Weiner DB. DNA drugs come of age. Sci Am. Jul 2010: 49-53.

183. Thomas C. Roadblocks in HIV research: five questions. Nat Med. 2009;15(8):855-859.

184. Heywood R. Clinical toxicity - could it have been predicted? Postmarketing experience. In: Lumley CE, Walker S, editors. Animal Toxicity Studies: Their Relevance for Man. Lancaster: Quay; 1990:57-67.

185. Spriet-Pourra C, Auriche M, editors. SCRIP Reports. New York: PJB; 1994.

186. Marwick C. Promising vaccine treatment for Alzheimer disease found. JAMA. 2000;284(12):1503-1505.

187. Manson JM. Biological considerations for risk assessment in developmental toxicology. In: McLachlan JA, Pratt RM, Markert CL, editors. Developmental Toxicology: Mechanisms and Risks. Banbury Report 26. Cold Spring Harbor Laboratory Press; 1987:307-322.

188. Shepard T, Lemire R. Catalog of Teratogenic Agents. 11th ed. Baltimore: Johns Hopkins; 2004.

189. Holmes B. Monkey genome springs surprise for human origins. New Sci. April 21, 2007.

190. Rhesus Macaque Genome Sequencing and Analysis Consortium, Gibbs RA, Rogers J, et al. Evolutionary and biomedical insights from the rhesus macaque genome. Science. 2007;316(5822):222-234.

191. Beniashvili DS. Experimental Tumors in Monkeys. Boca Raton, FL: CRC Press; 1994.

192. Wald C, Wu C. Of mice and women: the bias in animal models. Science. 2010;327(5973):1571-1572.

193. Willyard C. HIV gender clues emerge. Nat Med. 2009;15(8):830.

194. Holden C. Sex and the suffering brain. Science. 2005;308 (5728): 1574 .

195. Simon V. Wanted: women in clinical trials. Science. 2005;308 (5728):1517.

196. Couzin J. Human genetics. In Asians and whites, gene expression varies by race. Science. 2007;315(5809):173-174.

197. Couzin J. Cancer research. Probing the roots of race and cancer. Science. 2007;315(5812):592-594.

198. Gregor Z, Joffe L. Senile macular changes in the black African. Br J Ophthalmol. 1978;62(8):547-550. 
199. Willyard C. Blue's clues. Nat Med. 2007;13(11):1272-1273.

200. Cheung DS, Warman ML, Mulliken JB. Hemangioma in twins. Ann Plast Surg. Mar 1997;38(3):269-274.

201. Spielman RS, Bastone LA, Burdick JT, Morley M, Ewens WJ, Cheung VG. Common genetic variants account for differences in gene expression among ethnic groups. Nat Genet. 2007;39(2): 226-231.

202. Risch N. Dissecting racial and ethnic differences. $N$ Engl J Med. 2006;354(4):408-411.

203. Haiman CA, Stram DO, Wilkens LR, et al. Ethnic and racial differences in the smoking-related risk of lung cancer. $N$ Engl J Med. 2006;354(4):333-342.

204. Bachmanov AA, Reed DR, Beauchamp GK, Tordoff MG. Food intake, water intake, and drinking spout side preference of 28 mouse strains. Behav Genet. 2002;32(6):435-443.

205. Durrant C, Tayem H, Yalcin B, et al. Collaborative Cross mice and their power to map host susceptibility to Aspergillus fumigatus infection. Genome Res. 2011;21(8):1239-1248.

206. Holmes AM, Solari R, Holgate ST. Animal models of asthma: value, limitations and opportunities for alternative approaches. Drug Discov Today. 2011;16(15/16):659-670.

207. Morris JA, Royall JJ, Bertagnolli D, et al. Divergent and nonuniform gene expression patterns in mouse brain. Proc Natl Acad Sci U S A. 2010;107(44):19049-19054.

208. Bruder CE, Piotrowski A, Gijsbers AA, et al. Phenotypically concordant and discordant monozygotic twins display different DNA copy-number-variation profiles. Am J Hum Genet. 2008;82(3): 763-771.
209. Fraga MF, Ballestar E, Paz MF, et al. Epigenetic differences arise during the lifetime of monozygotic twins. Proc Natl Acad Sci U SA. 2005;102(30):10604-10609.

210. Javierre BM, Fernandez AF, Richter J, et al. Changes in the pattern of DNA methylation associate with twin discordance in systemic lupus erythematosus. Genome Res. 2010;20(2):170-179.

211. US Food and Drug Administration (FDA). FDA announces new boxed warning on Plavix: alerts patients, health care professionals to potential for reduced effectiveness [press release]. Silver Spring, MD: FDA; March 12, 2010 [updated December 3]. Available from: http://www. fda.gov/NewsEvents/Newsroom/PressAnnouncements/ucm204253. htm. Accessed March 12, 2010.

212. Weiss ST, McLeod HL, Flockhart DA, et al. Creating and evaluating genetic tests predictive of drug response. Nat Rev Drug Discov. 2008;7(7):568-574.

213. Americans for Medical Advancement (AFMA). FAQs about AFMA [web page on the Internet]. Goleta, CA: AFMA; 2010. Available from: http://www.afma-curedisease.org/faq.html. Accessed October 27, 2011.

214. AFMA: Advocates For Science-Based Medical Research [homepage on the Internet]. Goleta, CA: AFMA; 2010. http://www.afmacuredisease.org. Accessed October 27, 2011.
Medicolegal and Bioethics

\section{Publish your work in this journal}

Medicolegal and Bioethics is an international, peer-reviewed, open access journal exploring the application of law to medical and drug research and practice and the related ethical and moral considerations. The journal is characterized by the rapid reporting of reviews, case reports, guidelines and consensus statements, original research

Submit your manuscript here: http://www.dovepress.com/medicolegal-and-bioethics-journal

\section{Dovepress}

and surveys. The manuscript management system is completely online and includes a very quick and fair peer-review system. Visit http://www.dovepress.com/testimonials.php to read real quotes from published authors. 